\title{
TEORI PENGETAHUAN HUKUM DALAM USHUL FIKIH (KAJIAN TEORI HUKUM ALAM)
}

\author{
Umi Salamah \\ Program Studi Pendidikan Agama Islam \\ STIT Al-Mubarok Bandar Mataram Lampung Tengah \\ mbakumiku@gmail.com
}

\section{A. Pendahuluan}

Teori pengetahuan hukum yang dibahas dalam tulisan kali ini adalah teori hukum alam atau teori hukum kodrat. Berangkat dari syariat Islam tidak datang pada ruang hamba, hukum alam diakui sebelum datangnya ajaran Islam. Tidak semua hal diterangkan dalam syariat secara terperinci sehingga ada kelonggaran untuk manusia dalam menggali hukum.

Syariat Islam datang dengan menguatkan hukum yang ada, menbenarkan hukum yang kurang tepat dan menghapus hukum yang tidak sesuai syariat. Penetapan ini adakalanya berangkat dari tradisi yang ada dalam satu masyarakat dan melihat dari kemaslahatan manusia walaupun juga ada yang qodt'i.

Hukum dalam konsep positivistik adalah perintah dari yang berwenang dengan memenuhi prosedur tertentu. Berbeda hukum dalam Islam yaitu sapaan ilahi yang berhubungan dengan perbuatan manusia berupa tuntutan dan segala sesuatu yang bersifat normatif. Untuk mengetahui sapaan ilahi ini ada dua Paradigma hukum yaitu paradigma kekuasaan ilahi dan paradigma keadialan ilahi. Paradigma kekuasaan ilahi manusia mencari sapaan ilahi melalui wahyu. Dalam paradigma keadilan ilahi manusia menemukan sapaan ilahi selain dari wahwu juga dari alam dan kehidupan manusia.

Hukum alam memberikan informasi yang jelas betapa alam ini bergerak menurut ketentuan dan keteraturan. Selanjutnya hukum yang mengatur kehidupan manusia ini kadang memiliki perbedaan mendasar, yaitu menyangkut pemahaman hukum menurut ilmu hukum dengan hukum Islam yang bersumber dari wahyu. Menurut ilmu hukum, hukum itu hanya mengurus dan mengatur hubungan antar 
sesama manusia. Hukum itu hanya terdiri dari suruhan atau perintah dan larangan serta hak dan kewajiban. Apa yang dimaksud dengan nilai moral dan akhlak tidak tergolong hukum. Sebaliknya hukum menurut ajaran Al-Quran (hukum Islam), penegakan hukum berjalan sekaligus dengan pembinaan moral atau akhlak yang bersumber dari aqidah seperti imperatif, persuasif pilihan, persyaratan, dan kepenghalangan.

Wahyu tidak turun secara langsung terapi berangsur-angsur guna menjawab problem dan memberikan afirmasi pendapat yang sudah ada. Terbatas dalam kurun waktu 23 tahun sedangkan masalah-masalah tidak berhenti dan memerlukan penyelesaian. Berangkat dari paparan diatas dalam makalah ini akan dibahas bagaiman Kedudukan hukum alam dalam Islam, bagaimana hukum alam berperan dalam ushul fikih dan bagaimana penerapannya sebagai teori untuk menjawab problematika hukum Islam saat ini.

\section{B. Pembahasan}

\section{Epistimologi Usul Fikih}

Teori pengetahuan atau epistimologi berasal dari kata epis: pengetahuan dan logos: ilmu. Sedangkan pengetahuan adalah hasil olah rasio. Pengetahuan yang sistematis adalah ilmu. Epistimologi usul fikih mencangkup juga Teori usul fikih. Ada yang menyebut juga epistimologi hukum Islam juga sebagai metodologinya. ${ }^{27}$ Dalam hukum Islam ketika membahas epistimologi dikaitkan dengan wahyu dan akal.

Ada tiga masalah besar berkiatan kajian epistimoli usul fikih. Pertama bagaimanakah memperoleh pengetahuan yang sah mengenai hukum syar'i. Pertanyaan ini mencangkup masalah dengan cara apa penetahuan itu diperoleh atau apa sumber pengetahuan yang sah mengenai hukum Islam.

\footnotetext{
${ }^{27}$ Samsul Anwar, Metodologi Hukum Islam, pdf. hlm 111.
} 
Kedua, ulama usul fikih sepakat bahwa wahyu adalah sarana, meskipun bukan satu-satunya cara untuk memperoleh hukum syara' ${ }^{28}$ Wahyu sudah selesai Lalu generasi saat ini bagaimana mengetahui zaman lampau yang diluar jangkauan pengalaman empiris? Ketiga, bagimana dari teks-teks tersebut dapat disimpulkan hukum syar'i yang benar?

Untuk menjawab tiga masalah diatas dimulai dengan merujuk pada sumber pengetahuan. Dalam hal ini ada dua aliran yang pertama mengatakan bahwa sumber pengetahuan dalam hukum Islam adalah wahyu. Ini sering disebut aliran tradisionalis. Kedua aliran rasionalis bahwa sumber pengatahuan baik dan buruk dari akal tetapi akal terkadang tidak bisa menemukanya sehingga diperlukan konfirmasi dari wahyu. Ada juga pembagian sumbernya diperoleh dari mana berdasarkan: Aliran empiris: sumber pengetahuan dari pengalaman. Aliran rasionalis: sumber pengatuan dari rasionalitas.

Untuk menguji kebenaran bahwa dari mana pengethauan itu di dapat dengan ukuranya benar dan salah ada dua teori yaitu:

1. Teori korespondensi: sesuatu benar jika sesuai kenyataan. Tetapi dalam kenyataan banyak hal non empiris.

2. Teori koherensi: suatu benar jika pernytaan lain sesuai dengan kebenarannya. (koheren). Contoh untuk menguji demokrasi masa nabi dan khulafaur rasyidin.

Bahwa pengetahuan dalam usul fikih tidak hanya berdasarkan wahyu semata tetapi bersumber pada hukum alam.

\section{Teori Hukum Alam}

\section{Devinisi}

Menurut sebagian pendapat Hukum alam dalam yaitu bagian hukum kodrat yang berkaitan dengan semua aspek alam. ${ }^{29}$ Tetapi yang dimaksud dalam

${ }^{28}$ Samsul Anwar, Metodologi Hukum Islam.. hlm 116

29 Menurut Thomas Aquinas Hukum kodrat ini berangkat dari Tindakan manusia yang bertanggung jawab karena berdasarkan "bonun est faciendum et prosequendum, et malum vitandum", lakukan yang baik jangan lakukan yang jahat. Franz Magnis- Suseno, 13 tokoh etika (Yogyakarta: KANISIUS, 1997), 
bahasan ini bukan law of necere,seperti gratifikasi, adanya siang dan malam dan lainnya. Hukum alam yang dimaksud yaitu Necer law yaitu kaitannya dengan keadilan, hak asasi, kemaslahatan, yang bisa diakui oleh akal sehat.

Tujuan hukum yaitu untuk kemaslahatan manusia dunia akhirat. ${ }^{30}$

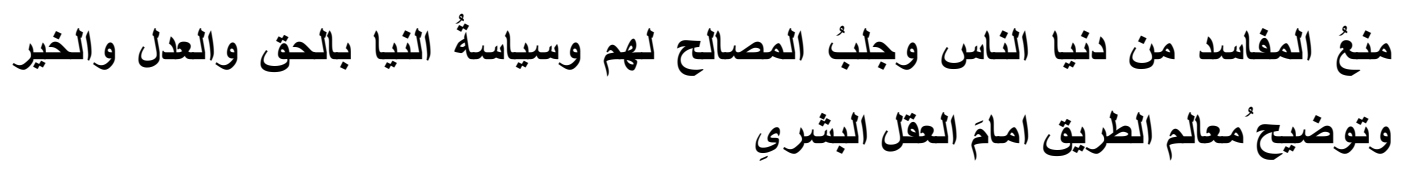

Artinya: mencegah kerusakan dari dunia manusia dan mendatangkan kemaslahtan kepada mereka, mengendalikan dunia dengan kebenaran dan keadilan dan kebajikan serta menerangkan tanda-tanda jalan yang harus dilalui dihadapan akal manusia.

Ada yang berpendapat hukum alam adalah hukum yang digambarkan berlaku abadi sebagi hukum yang norma-normanya berasal dari Tuhan yang maha adil, dari alam semesta dan dari akal budi manusia tanpa intervensi dari kelembangaan yang berbentuk perundang-undangan. ${ }^{31}$

Doktrin hukum alam, "the real law" hukum dalam pengertian yang sesungguhnya" bersifat kekal dan membentuk suatu sistem kesadaran hukum yang diasumsikan kekal, universal dan tidak digantikan oleh apapun dan siapapun, tak dapat dicaput oleh siapapun dan ororitas apapun karena pemberian dari tuhan dari mulia penciptaan hingga dunia berakhir. ${ }^{32}$

Menurut positifisme hukum, hukum alam adalah hukum yang senantiasa berevolusi dan mnyesuaikan diri kedalam gerak perubahan sebagai konsenkuensi berjalannya waktu. Artinya hukum bukan lagi sesuatu yang absolut tetapi relatif (menyesuaikan konfigurasinya pada ruang dan waktu tertentu). ${ }^{33}$ Sehingga hukum mencerminkan kebutuhan yang berubah-ubah menurut kebutuhannya. Menurut

${ }^{30}$ M. Hasbi Ash-shiddiqy, Falsafah Hukum Islam (Jakarta: NV Bulan Bintang, 1975), hlm. 177.

${ }^{31}$ Shadiq Dahlan, "Hukum Alam dan Keadilan", dalam Lili Rasjidi dan Arif Sidharta (ed.), Filsafat Hukum Mazhab dan Refleksinya, cet.ke-2 (Bandung: PT Remaja Rosdakarya,1994), hlm.17 . M. Shadiq Dahlan, "Hukum Alam dan Keadilan", dalam Filsafat Hukum Mazhab Dan Refleksinya, cet.ke-2 (PT Remaja Rosdakarya, 1994), hlm. 18.

${ }^{32}$ Herman Bakir, Filasafat Hukum Desain dan Arsitektur Kesejarahan, cet.ke-2 (Bandung: PT Refika Aditama), hlm.292

${ }^{33}$ Herman Bakir, Filasafat Hukum Desain dan Arsitektur Kesejarahan... hlm. 293-294 
Stemer ada dua pripsip dalam hukum sebagai kehendak khusus ini yaitu kehendak seeorang tidak bisa diwasiti oleh kehendak orang lain. Dan seorang yang mentaati peraturan dan menjalankan kewajibanya tidak akan diasingkan dari lingkungan masyarakat. ${ }^{34}$ Sehingga segala hukum yang mengabaikan hak-hak rakyat menurut hukum alam tidak sah.

Dalam tulisan Munir Fuady hukum alam didefinisikan sebagai suatu system ketentuan dan prinsip-prinsip yang dimaksudkan sebagai pedoman bagi sikap tindak manusia, yang bersifat independen dari peraturan hukum positif atau aturan hukum lainnya yang sedang berlaku di suatu Negara, system hukum alam tersebut didapatkan oleh pemikiran rasional dari manusia, yang tumbuh dan berkembang sesuai dengan hakikat perkembangan manusia yang benar, yaitu perkembangan mental, moral, dan hukum-hukum fisika. Atau dikatakan juga hukum alam adalah kebutuhan-kebutuhan dasar manusia yang diungkapkan melalui kecendrungan dasar manusia yang diketahui secara alamiah. ${ }^{35}$

Pandangan Plato tentang hukum alam ada perbedaan antara karya awalnya dan karya yang berikutnya, pada karya awalnya Plato mengatakan dalam tulisan yang diberi judul The Republic bahwa Negara seyogyanya dipimpin oleh para cendikiawan, yang bebas dan tidak terkait dengan hukum positif, namun pada keadilan. Kemudian dalam tulisan berikutnya yang diberi judul The Laws, dia mengatakan bahwa Negara harus melaksanakan keadilan berdasarkan kaidahkaidah tertulis. Sedangkan Aristoteles murid dari Plato memberi klasifikasi terhadap keadilan, baginya keadilan terdiri dari keadilan distributif dan keadilan korektif. Keadilan distributif bagi Aristoteles adalah tentang soal pembagian barang-barang dan kehormatan pada masing-masing orang sesuai dengan statusnya dalam masyarakat, sedangkan keadilan korektif merupakan menetapkan criteria dalam melaksanakan hukum sehari-hari yaitu pentingnya untuk

34 Otje Salman, "Teori-Teori Hukum Di Negara-Negara Berkembang:Perlunya Suatu Pendekatan Baru", dalam Filasafat Hukum Mazhab Dan Refleksinya (Bandung: PT Remaja Rosdakarya, 1994 ), hlm.132

35 Munir Fuady, Teori-Teori Besar (Grand Theory) Dalam Hukum, (Jakarta: Kencana, 2013), hlm. 17. 
menetapkan standar umum dalam melaksanakan hukuman. Selanjutnya Cicero mengajarkan tentang a true law (hukum yang benar), baginya hukum yang benar harus sesui dengan tight reason (penalaran yang benar) serta sesuai dengan alam, yang menyebar di antara kemanusiaan dan bersifat immutable dan eternal. ${ }^{36}$

Menurut Dias hukum alam yaitu ${ }^{37}$ :

a. Merupakan ideal-ideal yang menuntut perkembangan hukum dan pelaksanaanya.

b. Suatu dasar hukum yang bersifat moral yang menjaga jangan sampai terjadi suatu pemisahan secara total antara yang ada sekarang dan yang seharusnya.

c. Suatu metode untuk menemukan hukum yang sempurna

d. Isi dari hukum yang sempurna, yang dapat dideduksikan melalui akal.

e. Suatu kondisi yang harus ada bagi kehadiran hukum.

Mengkuti aristoteles, para sarjana seringkali kebanyakan menyamakan keadilan ilahiah dengan keadilan natural, tetapi tidak seperti pakar-pakar hukum natural yang memperhatikan hubungan keadilan dengan masyarakat, fakih memusatkan usaha mereka pada konsep keadialan dalam kaitannya dengan kehendak Tuhan dan menghubungkanya dengan nasib manusia. ${ }^{38}$

Jika dilihat dari pengertian di atas hukum alam sebagai teori dalam usul fikih tidak jauh dari yang sudah dirumuskan oleh tokoh pada masa yunani sampai saat ini. Bedanya dalam Islam, hukum alam pokok dasarnya tetap melihat pada Syari'ah. Sedangkan dalam pandangan para ahli hukum positif pokok dasarnya adalah manusia. Karenannya Hukum positif bisa bertentangan dengan dengan hukum alam, karena dibuat dengan berbagai kepentingan, sehingga bisa jadi tidak adil. $87-88$.

${ }^{36}$ Teguh Prasetyo dan Abdul Halim Barkatullah, Ilmu Hukum dan Filsafat Hukum, hlm.

${ }^{37}$ Teguh prasetia dan Abdul halim barkatullah, filsafat,teori, dan ilmu hukum: pemikiran menuju masyarakat yang berkeadilan dan bermartabat, cet.ke-2 (jakarta: rajawali press, 1013), hlm100-101

${ }^{38}$ Abdulaziz A. Sachedina, penciptaan tatanan sosial yang adil dalam Islam, dalam Mumtaz ahmad (ed), Masalah-Masalah Teori Politik Islam, cet. Ke-3 (Bandung:Mizan, 1996), hlm.162. 
2. Pembagian hukum alam

Hukum alam dibagi menjadi 2, yaitu: rasional (yang bisa dinilai) dan relegius (yang diwajibkan oleh Tuhan).

Pembagian hukum alam:

- Hukum alam religius

- Hukum alam non religius

Dalam Islam tidak ada pembagian hukum karena semua dari Tuhan. Hukum alam dalam Islam tidak berkembang. Hanya ada satu aliran yang menerima hukum alam. Sebagimana pendapat Ibnu Mas'ud: apa yang baik dalam kesadaran masyarakat baik dalam pandangan Tuhan.

\section{Hukum Alam Dalam Pembentukan Peraturan Suatu Negara}

Seperti dalam uraian di atas hukum alam adalahdalam hukum positif sebagai pokok dasar pembentukan peraturan perundang-undangan. Hal ini sebagai penyeimbang peraturan yang tidak sesuia dengan keadilan. Karena hukum bersifat memaksa. ${ }^{39}$

Sepanjang sejarah dapat diketahui banyaknya peranan hukum ini dalam berbagai fungsi, seperti misalnya Dipergunakannya hukum alam untuk mengubah hukum perdata Romawi yang lama menjadi satu sistem hukum umum yang berlaku di seluruh dunia. Dan sebagai dasar hukum internasional dan dasar kebebasan perseorangan terhadap pemerintah yang absolut.

Empat Macam Hukum Menurut Thomas Aquinas:

a) Lex Aeterna

Hukum abadi yang menguasai seluruh dunia. Hukum ini bersumber dari Tuhan dan menjadi dasar bagi semua hukum yang ada. Rasio ini tidak dapat ditangkap oleh pancaindra manusia. Hanya sebagian kecil saja yang disampaikan kepada manusia.

\footnotetext{
${ }^{39}$ Baca lengkapnya tentang teori hukum dengan pengertian hukum adalah tatanan pemaksa normatif, Hans Kelsen, Teori Hukum Murni Dasar-Dasar Ilmu Hukum Normatif, Raisul Muttaqin (terj), cet.ke-8 (Bandung:Nusa Media, 2011)
} 
b) Lex Divina

Bagian dari rasuo Tuhan yang dapat ditangkap atas dasar wahyu yang diterimanya dan sebagian lex divina ini disebut.

c) Lex Naturalis

Merupakan hukum alam. Dikatakan bahwa hukum ini merupakan perwujudan lex aeterna pada rasio manusia. Atas dasar ini maka manusia dapat melakukan suatu penilaian, dapat menetukan mana yang baik dan mana yang buruk.

d) Lex Positiva

Yang dibagi atas hukum positif yang dibuat oleh Tuhan yang terdapat dalam kitab-kitab suci dan hukum positif yang dibuat manusia. Hukum positif ini merupakan pelaksanaan dari hukum alam oleh manusia atas dasar persyaratan yang khusus yang diperlukan keeadaan dunia.

Thomas Aquinas menerima hukum kodrat sebagai prinsip-prinsip segala hukum positif, yang berhubungan secara langsung dengan manusia dan dunia sebagai ciptaan Tuhan. Prinsip-prinsip ini dibagi dua, yakni :

1. Prinsip hukum kodrat primer, yakni prinsip hukum yang telah dirumuskan oleh para pemikir stoa pada zaman klasik: hidup secara terhormat, tidak merugikan seorangpun, memberikan tiap-tiap orang menurut haknya.

2. Prinsip hukum kodrat sekunder, yakni norma-norma moral, umpanya jangan membunuh.

Dapat dikatakan bahwa fungsi hukum alam dalam tatanan hukum positif yaitu sebagai kontrol keadilan dan sebgai mengisi kekosongam hukum. Sehingga dibutuhkan hukum kodrat atau hukum alam yang berlaku universal yang akan menetapkan secara hakiki peraturan-peraturan dasar setiap tatanna hukum positif.

\section{Determinasi Wahyu dan Hukum Alam dalam Ushul Fikih}

Dalam agama Islam dipahami bahwa peraturan Allah ada dua yaitu pertama: Hukum agama (hukum Qur'aniyah) yang tertulis (mathluwwi) di dalam kitab-kitab Allah, seperti larangan berzina, riba, mengumpat dan perintah berdzikir, shalat, sabar, tawakkal, dll. Kedua hukum alam (hukum Kauniyah, 
ghair mathluwwi = tidak tertulis) tetapi melekat pada alam itu sendiri. Beberapa contoh hukum alam adalah hukum gravitasi, hukum rotasi, hukum daur, dll. ${ }^{40}$

Hukum alam adalah ciptaan Allah, hukum Al-Qur'an (Quraniyah) pun ciptaan Allah. Secara logika tidak mungkin kedua hukum itu bertentangan. Apaapa yang dilarang oleh Al-Qur'an pasti sesuai menurut hukum Alam, sebaliknya apa-apa yang dilarang oleh Al-Qur'an pasti buruk menurut hukum Alam. Apa yang dianggap berbahaya menurut hukum Alam pasti oleh Al-Qur'an diharamkan. Sebaliknya apa-apa yang baik menurut hukum Alam, pasti dianjurkan oleh AlQur'an. Inilah azas kesatuan atau disebut azas tauhidullah. Dengan demikian dalam segala aktivitas manusia harus menyelaraskan dengan kedua hukum tersebut secara bersamaan. ${ }^{41}$

Untuk menselaraskan antara hukum alam dan syariat Islam, dengan mengetahui tujuan hukum syariat yaitu untuk mewujudkan kemaslahatan semesta, menegakkan keadilan, dan menghilangkan kezdaliman serta kerusakan dari kehidupan dunia. Sehingga dalam menerapkan dan merumuskan hukum harus melihat perubahan situasi, kondisi dan tradisi.

Syatibi membagi dalil syara' terdiri dari dua bagian yaitu teks naqli dan aqli (merujuk kepada akal). Antara kedua dalil tersebut saling membutuhkan. Untuk menerapkan dalil naqli perlu menggunakna penalaran akal dan untuk menerima dalil aqli dengan berdasar pada naqli. ${ }^{42}$

Hukum Islam yang keberadaanya sebagain bagian yang tak terpisahkan dari masyarakat seharusnya bisa berlaku universal dan humanis sehingga tidak terbelenggu dalam dunia modern saat ini. Nas\} yang di dalamnya terdapat ketentuan yang diatur secara terperinci tetapi juga ada yang memerlukan penafsiaran Rasulullah atau penjelasan yang lebih lanjut. penjelasan Rasulullah yang bersifat kondisional ini tidak menjangkau seluruh peristiwa. Realitasnya

\footnotetext{
40 Konsep Alam dalam Islam, http://ramaridho777.blogspot.com/2012/02/konsep-alamdalam-islam.html akses 11-11-2014

${ }^{41}$ Ibid., hlm. 21 .

${ }^{42} \mathrm{Abu}{ }^{\text {Ishaq }}$ As-Syatibi, Al-Mubawaqat Fi Usul As-Syariah, juz III (t.ttp.: Dar al-fikr, t.t.)
} 
banyak kejadian yang muncul dan akan muncul yang tidak ditemuai secara harfiah dalam nas baik al-Qur'an maupun hadis, namun ditemukan secara rasional dibalik harfiahnya. $^{43}$

Penerapan hukum alam dalam hal ini menjadi rujukan dan menetapan hukum berdasarkan hadis dialog antara Rasulullah dan Muaz bin Jabal ketika diutus menjadi Qadi di Yaman. ${ }^{44}$ Bangunan ijtihad dalam Hadis tersebut adalah tiga rujukan pokok hukum Islam adalah al-Qur'an, sunnah dan ijtihat. ijtihad dalam kerangka itu dipahami dengan ijtihad komunal para sahabat dengan tradisi ijma, qiyas, maslahah dan berdasarkan pilihan hukum masyarakat Islam yang ada (urf).

Usul fiqh sebagai jempatan antar teks dan realita juga mampu memberikan kemaslahatan manusia, mengaplikasikan dan mengembangkan metodologi yang falid dan akuntabel. Sebagai metodologi yang bersifat eksperimentatif usul fiqh tidak hanya menjadikan teks sebagai satu-satunya sumber pengetahuan akan tetapi empirisme melalui al-sibr wa al-taqsim merupakan referensi yang dipertimbangkan. ${ }^{45}$

Tetapi ulama kalam berselihih paham terhadap masalah menta'lil hukum walaupun mereka mengakui hukum bertujuan untuk kemaslahatan. Ada tiga pemdapat terhadap penyariatan hukum mengandung maslahat dan apakah maslahat itu mengaitkan hukum syara'.

Golongan pertama berpendapat bahwasannya sama sekali tidak boleh mentaklil hukum syara' dengan maslahat-maslahat dan tidak boleh dikaitkan dengan maslahat. Kedua pengatkan bahwa maslahat itu dapat dijadikan illat sebagai hukum suatu tanda sahaja bagi hukum, bukan sebagai suatu penggerak yang menggerakkan Allah menetapkan hukum itu. yang ketiga perpandangan

${ }^{43}$ Saifuddin Zuhri, Mas\}lahłah Implikasinya Sebagi Sumber Hukum Islam Studi tentang Konsep Najmuddi>n at\}-T\}ufi, "Desertasi" tidak diterbitkan.pps uin sunan kalijaga Yogyakarta, 2008.hlm 220.

${ }^{44}$ Ahmad Hafidh, Meretas Nalar Syariah (Yogyakarta: Teras, 2011), hlm.132

${ }^{45}$ Muhammad Anis Masduqi, Usul Fikih dan Rekontruksi Hukum (Studi Pemikiran Hasan Hanafi Dalam Mi Al-Nas\} Ila Al-Waqi'dan Lerefansinya Dalam Buku 1 Tenta Ng Perkawinan Kompilasi Hukum Islam), "tesis” tidak diterbitkan PPS Uin Sunan Kalijaga Yogyakarta, 2010. 
segala hukum Allah ditaklilkan dengan maslahat, karena Allah telah berjanji sedemikian dan karena Allah Tuhan yang senantiasa mencurahkan rahmat atas hamba-Nya, menolak dari pada mereka dan melenyapkan kepicikan dan kesempitan. ${ }^{46}$ Dalam perbedaan pandangan ini hanyalah sebatas teori karena pada dasarnya para ahli hukum menetapkan bahwa segala hukum syara' adalah wadah kemaslahatan yang hakiki.

\section{Macam-Macam Hukum Alam dalam Usul Fikh}

Syariat Islam terlihat adanya keluwesan dalam sektor kemanfaatan atau medan netral. Yang secara sengaja tidak tertuang dalam teks-teks agama. Hal ini diperlukan ijtihat dengan melihat dari pertimbangan akal, hukum alam dan kemaslahatan manusia. ${ }^{47}$

Hal ini dapat dilihat dari sabda nabi: Sesunggunya Allah telah menetapkan batas-batas, maka janganlah kalian melanggarnya; dan mewajibkan beberapa hal,maka janganlah kalian mengabaikannya,dan mengharamkan beberapa hal, maka janganlah kalian merusaknya dan ia diam akan hal-hal tertentu karena rahmat bagi kaliandan bukan karena ia lupa, maka janganlah kalian mempertanyakanya. Dan berdasarkan firman Allah: Hai orang-orang yang beriman, janganlah kamu menanyakan (kepada Nabimu) hal-hal yang jika diterangkan kepadamu akan menyusahkan kamu dan jika kamu menanyakan di waktu Al Quran itu diturunkan, niscaya akan diterangkan kepadamu, Allah memaafkan (kamu) tentang hal-hal itu. Allah Maha Pengampun lagi Maha Penyantun.

${ }^{46}$ Golongan pertama diwakili oleh Asy’ariyah dan Dhahariyah. Golongn kedua sebagian ulama syafiiyah dan hambaliyah dan yang ketiga oleh mu'tazilah, maturidiyah sebagian ulama hambaliyah dan semua ulama malikiah. M. Hasbi Ash-Shiddiqy, Falsafah Hukum Islam...hlm182183

47 Yusuf Qardhawi, Keluwesan dan Keluasan Syariat Islam dalam,Menghadapai Perubahan Zaman, hal.6. 
Hukum Allah dapat ditemukan melalui tiga bentuk ${ }^{48}$ :

1. Hukum itu dapat ditemukan dalam ibarah nas $\}$ sesuai dengan yang disebut secara harfiah. Yang demikian hukum ditetapkan dari apa yang tersurat.

2. Hukum Allah tidak dapat ditemukan secara harfiah dalam nas $\}$ tetapi dapat ditemukan melalui isyarah atau petunjuk lafad yang disebut dalam teks nas\}. Hukum semacam ini disebut hukum apa yang tersirat dalam teks nas\}.

3. Hukum Allah tidak dapat ditemukan dari harfiah ladaz dan tidak pula dari isyarahnya, tetapi dapat ditemukan dalam jiwa dari keseluruhan maksud syariah menetapkan hukum.

Hukum yang ditetapkan berdasarkan dari apa yang tersirat dibalik teks disebut ijtihat maknawi atau ijtihat istis $\} l a>h\}$, yaitu ijtihat yang berusaha menjelaskan dan menetapkan hukum syariat yang tidak ada nas \}nya atau tersirat dalam nas dengan menggunakan ra'yu berdasarkan kaidah istislahi. ${ }^{49}$ Menurut Wahbah Zuhaili termasuk ijtihad syar'i meliputi ijma', qiyas, istihsan, istislah, 'urf, istishab dan lainnya. ${ }^{50}$

\section{Urf sebagai Penetapan Hukum dalam Usul Fikih}

Urf adalah bahasa arab, dalam bahasa Indonesia disebut tradisi atau adat, dalam bahasa inggris disebut custom,practice, legal practice. Urf adalah kebiasaan (adat) perilaku yang terkenal di masyarakat dalam kehidupan seharihari yang kemudian menjadi adat istiadat turun temurun baik yang berupa ucapan aupun berbuatan, baik yang umum maupun yang khusus. ${ }^{51}$

Ada yang mengartikan urf dengan berlandaskan pada firman Allah surat al-A'raf (7:199) mengartikan urf al-ma'rifah yaitu pengenalan secara baik (ma'ruf) terhadap sesuatu dan diterima oleh akal sehat. ${ }^{52}$

${ }^{48}$ Saifuddin Zuhri, Mas lah lah Implikasinya Sebagi Sumber Hukum Islam Studi, hlm. 221.

${ }^{49}$ Ibid., hlm. 221.

${ }^{50}$ Bahbah Zuhaili , Usul Fikih

${ }^{51}$ Yusuf Qardhawi, Keluwesan dan Keluasan Syariat Islam Dalam Menghadapi Perubahan Zaman, (terj) tim pustaka firdaus (Jakarta: Pustaka Firdaus, 1996), hlm.30. dan M. Hasbi Ashshiddiqy, Falsafah Hukum Islam...hlm. 475

${ }_{52}$ Duski Ibrahim, Metode Penetapan Hukum Islam, 
Ketika Islam datang bangsa arab telah memiliki berbagai tradisi. Islam mengakui tradisi yang sesuai dengan tujuan dan prinsip Islam. Selain itu Islam meperbaiki tradisi-tradisi arab yang sehingga sesuai dengan Islam.

Hal-hal yang tidak jelas dalam syariat diatur dan dijelaskaan dengan urf yang benar. Dengan disesuaikan dengan tradisi. Karena Tuhan tidak menurunkan syariat secara terperinci. Seperti contoh firman Allah yang artinya " dan kewajiaban ayah memberi makan dan pakain kepada para ibu secara baik-baik,”. Untuk menjelaskan bentuk bagaimana pengaturan nafkah, urf dijadikan landasan. ${ }^{53}$ Karenanya ada yang mengatakan:

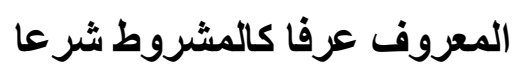

Artinya: sesuatu yang ma'ruf pada urf sesuatu yang disyaratkan pada syara'.

Ibnu abidin yang dikutip oleh hasbi ash-shidiqi menyatakan bahwa "urf pada syara'mempunyai penghargaan atasnyalah terkadang-kadang didasarkan hukum" dan adat kebiasaan adalah salah satu dari hujjah agama terhadap sesuatu yang tidak ada nas $\}.{ }^{54}$ masalah yang didiamkan oleh nas\} adalah al-'afwu (kemaafan).

Para imam mazhab seperti imam Malik banyak melihat dari kebiasaan dari penduduk Madinah untuk menghukumi sesuatu. begitupun Imam Syafi'i dalam qoul jadidnya dipengaruhi adat kebiasaan penduduk Mesir.

Menurut as-syatibi hubugan adat dan hukum Islam adalah hubungan kausalitas. adat adalah sabab (penyebab) bagi adanya musabab (hukum). ${ }^{55}$ Seperti kemampuan melakukan sesuatu perbuatan atau baligh diatur oleh syari' tentang pentaklifan hukunya.

Urf dapat menjadi sumber hukum jika memenuhi 3 kriteria yaitu pertama urf tidak berlawanan dengan nas \} yang tegas. Kedua apabila adat itu telah menjadi adat yang terus menerus berlaku dan berkembang dalam masyarakat.

\footnotetext{
${ }^{53}$ Yusuf Qardhawi, Keluwesan dan Keluasan Syariat Islam, hlm. 31.

${ }^{54}$ Hasbi .. hlm 476.

${ }^{55}$ Duski Ibrahim, Metode Penetapan Hukum Islam...hlm. 108
} 
Yang ketiga urf yang berlaku urf yang umum, karena hukum yang umum tidak dapat ditetapkan dengan urf yang khas. ${ }^{56}$

Syatibi membagi adat menjadi 2 macam, pertama adat yang ditetapkan dan ditiadakan oleh dalil syara'. Seperti adanya perintah wajib atau mubah, adanya larangan haram atau makruh. Atau syarak mengizinkan untuk melakukan atau meninggalkan. Yang kedua yaitu adat-adat yang berlaku pada manusia tanpa ada dalil syara' secara khusus yang menetapkan atau meniadakannya.

2. Qiyas (Analogi Rasional)

Qiyas memainkan peran utama dalam ijtihad Islam. qiyas adalah meyepadankan hal yang belum ada nas \} hukumnya dengan hal lain yang sudah ada hukumnya karena adanya suatu kuasa hukum ("illat) yang mmepertemukan keduanya dan tidak ada hal penting yang memisahkan keduanya. ${ }^{57}$

Para ulama memakai qiyas untuk beberapa hal misalnya: Qiyas "makanan pokok sutau negara" dengan jenis makanan yang disebutkan di dalam hadis (qurma, anggur, gandum dan beras) untuk zakat. Sahabat Umar pun mengunakan qiyas untuk mengambil zakat dari kudayang harganya sama dengan beberapa unta dan kambing. ${ }^{58}$

3. Istihsan

Para ahli fikih membagi istihsan berdasarkan sandaran dalilnya:

a) Istihsan yang sandaran dalilnya adalah urf.misalnya akad istisna.sekalipun ini merupakan akad atas sesuatu yang belum ada wujudnya,melalui istihasan dapat disahkan karena hal ini menurut tradisi bukan sesuatu yang janggal.demikin pula mewakafkan sesutau yang bisa berpindah tempat, misalnya kitab. Wakaf seperti ini tidak ada nashnya, namun sah untuk dilakukan karena menjadi tradisi.

b) Istihsan yang sandaran dalilnya keadaan darurat. Misalnya, dimaafkanya ciparatan air kencing atau pelanggaran kecil yang tak mungkin dihindari.

\footnotetext{
${ }^{56}$ Hasbi .. hlm 476.

${ }^{57}$ Yusuf Qardhawi, Keluwesan dan Keluasan Syariat Islam, hlm. 9.

${ }^{58}$ Ibid., 9
} 
c) Istihsan yang sandaran dalialnya adalah kemaslahatan.misalnay membebankan ganti rugi kepada mitra usaha.

d) Istihsan yang sandaran dalilnya menghilangkan kesulitan. Mislanya, kemungkinan terjadinya sedikit manipulasi dalam muamalah.

Metode istihsan antara lain dipakai untuk memutuskan perkara fikih yang disebut "masalah musytarakah" atau masalah himariyyah" dalamhukum waris. Masalah ini muncul apabila seorang wanita wafat dan menggilkan suami, ibu, saudara seibu dan saudara seibu sebapak. Pembagaian warisnya dengancara qiyas adalah separuh untuk suami,seperenam untuk ibu,dan sepertiga untuk saudara seibu.sedangkan saudara seibu-sebapakhanya mendapatkan asabahdari pembagian itu. jika ternyata tidak ada kelebihan atau sisa dari pembagian itu. tentu saja mereka tidak memperoleh apa-apa.

Khalifah umar pernah menghadapi masalah seperti ini. Dalam suatu pembagian warisan, ia tidak memberikan apa-apa kepada saudara seibu-sebapak dari wanita yang meninggalkan warisan itu. salah satu dari mereka berkata, wahai amirulmukminin andaikata ayah kami keledai,tidaklah kami datang dari suatu ibu yang sama? Mendengar itu umar membatalkan pembagian waris yang sudah diputuskannya.kemudian ia membagi bagian warisan untuk mereka secara rata. ${ }^{59}$

Dari sini terlihat sekali bahwa penyelesaikan suatu perkara tidak bisa lepas dari hukum alam. Hukum syariah tidak serta merta diterapkan tetapi juga melihat hubungan kekerabatan tersebut.

4. Istislah

Istislah adalah menjadikan kemaslahatan umum sebagai acuan dalil (istidlal). Di dalam syariat menurut syatibi maslahat bisa diterima dengan tiga syarat yaitu

a. Maslahat secara hakiki harus masuk akal;

b. Maslahat harus sejalan dengan tujuan umum syariat, tidak bertentangan dengan salah satu prinsip pokokatau dalil qot'inya;

\footnotetext{
${ }^{59}$ Ibid., 14-15.
} 
c. Maslahat itu harus dimaksudkan untuk mejaga hal yang bersifat dharuri atau menghilangkan kesulitan agama.

\section{Simpulan}

Hukum alam berperan dalam ushul fikih dan penerapannya sebagai teori untuk menjawab problematika hukum Islam saat ini. Keadilan ilahi tidaklah saklek dengan nas \} yang ada tetapi juga ada ruang dan diberikan keleluasan untuk mejadi pedoman. Tidak semuanya harus berdasarkan dalil naqli tetapi juga mempertimbangkan dalil aqli atau dalil-dalil kauniyyah demi kemaslahatan umat manusia. Kedua hukum itu semuanya saling terkait. Teori hukum alam dalam hukum diakui karena representasi dari paradigma keadilan ilahi. 


\section{DAFTAR PUSTAKA}

Abdulaziz A. Sachedina, Penciptaan Tatanan Sosial yang Adil dalam Islam, dalam Mumtaz ahmad (ed), Masalah-Masalah Teori Politik Islam, Bandung: Mizan, 1996.

Abu ${ }^{\text {Ishaq }}$ As-Syatibi, Al-Mubawaqat Fi Usul As-Syariah, t.ttp.: Dar al-fikr, t.t

Ahmad Hafidh, Meretas Nalar Syariah ,Yogyakarta: Teras, 2011.

Bahbah Zuhaili , Usul Fikih, Semarang: Toha Putra, tt.

Herman Bakir, Filasafat Hukum Desain dan Arsitektur Kesejarahan, Bandung: PT Refika Aditama.

M. Hasbi Ash-shiddiqy, Falsafah Hukum Islam, Jakarta: NV Bulan Bintang, 1975.

Franz Magnis- Suseno, 13 tokoh etika, Yogyakarta: KANISIUS, 1997.

Muhammad Anis Masduqi, Usul Fikih dan Rekontruksi Hukum (Studi Pemikiran Hasan Hanafi Dalam Mi Al-Nas\} Ila Al-Waqi'dan Lerefansinya Dalam Buku 1 Tenta Ng Perkawinan Kompilasi Hukum Islam), "tesis" tidak diterbitkan PPS UIN Sunan Kalijaga Yogyakarta, 2010.

Munir Fuady, Teori-Teori Besar (Grand Theory) Dalam Hukum, Jakarta: Kencana, 2013.

Filasafat Hukum Mazhab Dan Refleksinya, Bandung: PT Remaja Rosdakarya, 1994.

Saifuddin Zuhri, Maslahah Implikasinya Sebagi Sumber Hukum Islam Studi tentang Konsep Najmuddin at-Tufi, "Desertasi" tidak diterbitkan, PPS UIN Sunan Kalijaga Yogyakarta.

Shadiq Dahlan, "Hukum Alam dan Keadilan", dalam Lili Rasjidi dan Arif Sidharta (ed.), Filsafat Hukum Mazhab dan Refleksinya, Bandung: PT Remaja Rosdakarya,1994.

Teguh Prasetia dan Abdul Halim Barkatullah, Filsafat, Teori, dan Ilmu Hukum: Pemikiran Menuju Masyarakat Yang Berkeadilan Dan Bermartabat, Jakarta: Rajawali Press, 2013.

Yusuf Qardhawi, Keluwesan dan Keluasan Syariat Islam Dalam Menghadapi Perubahan Zaman, (terj) Tim Pustaka Firdaus, Jakarta: Pustaka Firdaus, 1996.

KBBI, http://ebsoft.web.id.

http://ramaridho777.blogspot.com/2012/02/konsep-alam-dalam-islam.html akses $11-11-2014$ 